\title{
More Power, Less Sympathy \\ The Response of IGOs in Western Europe to Unwanted Migration during Economic Crises Compared
}

\author{
Irial Glynn
}

\begin{abstract}
This article chronicles the influence of intergovernmental organisations (IGOs) over unwanted migration in Western Europe since the 1930s. It pays particular attention to what occurred during times of economic crisis, especially the Great Depression in the 1930s, the recession-hit 1970s and early 1980s, and the current global financial difficulties. The IGOs under consideration are the League of Nations during the 1930s and the European Commission from the 1970s onwards. The European Commission's ability to influence West European states' policies on unwanted migration has grown considerably since the League of Nations' unsuccessful attempts in the 1930s, especially in the lead-up to the current economic crisis. This increase in power has been offset, however, by a decrease in the European Commission's sympathy as Brussels increasingly regards unwanted migration as a security and justice issue rather than as a social and cultural one in a move that bears close resemblance to the stance of West European states.
\end{abstract}

Keywords: Great Depression · Unwanted migration · West Europe · Economic crisis - IGOs

\section{Introduction}

The aim of this paper is to sketch the role of IGOs in migrant affairs during various periods of economic crisis in Europe. The article summarises the key developments in various Western European countries from a pan-European perspective and does not attempt to specify the tendencies of one single country. The three periods compared here are 1930s, the 1970 and the current crises.

During the crisis decade of the 1930s, the League of Nations' High Commissioner for German Refugees unsuccessfully called for European countries to treat refugees with hospitality in the face of increasing hostility. During the stagnant 1970s, and continuing into the early 1980s, the European Commission similarly urged Eu- 
ropean member states to treat its non-European migrants in a more sympathetic fashion. Despite these calls, neither the High Commissioner in the 1930s nor the European Commission during the so called oil price crises of the 1970s held considerable sway in challenging states' migrant policies. More recently, the European Commission's ability to affect member states' policies has increased dramatically ever since migration became a shared responsibility in the 1990s. By charting how IGOs reacted to states' migration policies in Western Europe since the 1930s, and particularly during times of economic crisis, this paper will argue that the European Commission currently responsible for migration generally takes a less benevolent view of the rights of unwanted migrants than their Commission precursors in the 1970s and early 1980s and the League of Nations' High Commissioner for German Refugees in the 1930s. Despite the inherent difficulties that arise from analysing different socio-economic and political settings, examining the role of IGOs over time can lead to intriguing findings; as Peter Kolchin notes, comparing cases "can create an awareness of alternatives, showing developments to be significant that without a comparative perspective might not appear so" (Kolchin 1982: 64-5).

To expound and substantiate the argument put forward, the first part of the article will concentrate on the international reaction in Western Europe to unwanted migration during the Great Depression in the 1930s. Subsequently, the paper will discuss how the European Commission responded to states' treatment of unwanted migrants during the time of the oil price crises in 1973 and 1979. Thereafter, the rise in influence of the European Commission on migration-related issues will be illustrated, as will the repercussions for unwanted migrants in the current crisis. As will become apparent in this paper, West European governments often introduced additional measures to prevent the arrival or stay of certain migrants during economic depressions and recessions. These migrants can be, as will be demonstrated below, refugees, economic migrants or asylum seekers. They are all "unwanted" by governments during times of economic crisis; hence the use of the term "unwanted migrants" throughout to describe those migrants who received special treatment from governments during times of economic difficulty in Western Europe.

Various contemporary (e.g., Simpson 1939; Thompson 1938) and later accounts (e.g., Arendt 2004; Caron 1999; Marrus 1985; Skran 1995; Beck 1999; Hathaway 2005; Heim 2010) have been written about the League of Nations' efforts to support unwanted migrants during the 1930s. Similarly, certain experts have considered the reaction of the European Commission to states' attempts to enforce additional measures on unwanted migrants during the oil price crises of the 1970s (e.g. Simmonds 1988; Berlinghoff 2009). Rarely, however, have scholars compared and contrasted the treatment of unwanted migrants in Western Europe during different economic crises to discover whether any similarities and differences exist between them. The extensive and extended nature of the current global financial crisis has resulted in the publication of numerous economic surveys that have reanalysed in some detail the response to past slumps and downturns with the aim of demonstrating whether the world can learn anything from previous experiences (e.g. Reinhart/Rogoff 2009; Bierman Jr 2010). By analysing previously understudied primary sources from IGOs in past decades and by drawing on certain recent studies written on the eras in 
question, this article similarly intends to chronicle the diachronic development of international protection in Western Europe for unwanted migrants since the 1930s. By doing so, it will highlight some past trends in the treatment of unwanted migrants in Western Europe during periods of economic instability that may reoccur during the present crisis.

\section{Tightening the borders: The 1930s}

Improved transportation and a more globalised world heralded in a notable increase in movement during the so-called "age of mass migration" between 1850 and 1914, especially from Europe, India and China (Hatton/Williamson 1998; Lucassen/Lucassen 2009: 374; McKeown 2004: 166). Restrictive measures linked to the rise of ethnic nationalism did begin to arise sporadically in various jurisdictions across Europe from the end of the nineteenth century onwards, notably in Prussia in the 1880s and 1890s (Reinecke 2008: 66-70) and in England in the early twentieth century (Collyer 2005: 289). Instead of lifting their bellicose measures following the end of the First World War, some West European countries reinforced them (Torpey 2003: 84). Significantly, the United States, which had accepted approximately one million immigrants annually up until 1914, was one of the countries to initiate measures to stem migration after the First World War. Following John Dillingham's negative reports on immigration, the American Congress superseded President Woodrow Wilson to implement legislation in 1917, leading to the insertion of various immigration restrictions in 1921 and 1924 (Hatton/Williamson 2004a; Timmer/Williamson 1998). West European states, which had actually relaxed their immigration policies following the end of the First World War - although the security measures brought in during the war did not all disappear - began instigating more restrictive policies during the recession-hit 1930s (Caestecker/Moore 2010: 314-5). Previously, these unwanted migrants might have found a home across the Atlantic, as had occurred during former economic crises in the nineteenth century. This time, however, Western European countries had to adapt to the extra burden that the disappearance of America as an emigration destination placed upon them.

Hobsbawm (1992) has termed the interwar years the "apogee of nationalism", as new approaches to nationalism perceived that a named human population shared a common history, territory and language. Anyone considered ineligible from sharing these traits, such as ethnic minorities or migrants, became conspicuous in the eyes of the public and governments. To amplify this even further, the post-WWI development in many Western European countries of modern systems of social organisation - the so-called "welfare state" - led to an even greater distinction between citizens and non-citizens (Hathaway 2005: 83). The consequences of increases in passport control, as well as the popular support for the ethnic state all over Europe meant that entry - and stay - became more difficult to attain for refugees and economic migrants alike.

The 1930s saw a noticeable decrease in the number of people trying to migrate compared to the 1920s, when over one million Russian refugees had fled to various 
European countries (Jaeger 1999: 1). Nevertheless, the worsening economic conditions that followed the 1929 Great Wall Street Crash and the growth in power of the middle and working classes, who voiced their concern about the perceived threat from foreign labour, resulted in most migrants in the 1930s receiving considerably more hostile treatment than their 1920s' counterparts. States strengthened their enforcement mechanisms to restrict and expel unwanted migrants as the 1930s progressed. German Jews fleeing Nazism often received the most rancorous reception. Due to increasing stipulations barring newcomers from taking up employment during the 1930s financial depression, it fell to Jewish refugee aid committees in Western Europe to reassure governments that they would provide the financial support necessary to ensure that German Jews would not place an undue burden on receiving states. Despite this initially resulting in relatively sympathetic Western European policies towards German Jews in 1933, when the exodus began, these same aid committees quickly saw their funds deplete as a result of the size of the influx (Caestecker/Moore 2010: 219). Significantly, as German Jews continued to arrive in Western Europe, national governments preferred to designate them as temporary refugees rather than as political refugees because of the fear that this would entitle those same migrants to certain benefits associated with liberal traditions of political asylum (Caestecker/Moore 2010: 317). Events in 1938 made it impossible for West European states to deny that German and Austrian Jews were anything other than political refugees; as a result they stepped up their efforts to strengthen their external controls, through strict visa policies and improved border controls, to try to stem the flow (Caestecker/Moore 2010: 238).

The international reaction to the German refugee crisis derived principally from the League of Nations' efforts to find some kind of a solution. To aid those fleeing Nazi Germany, the intergovernmental League appointed a High Commissioner responsible for German refugees, with the American James McDonald taking up the post in October 1933. McDonald noted in 1935 that 'the daily grace in the High Commissioner's office was "Thank God for Palestine"' (Marrus 1985: 163), on account of its absorption of Jewish refugees. But the Arab Revolt of 1936 made the British wary of the potential effect continuing Jewish emigration could have on its rule over Palestine. Thereafter, the British government repeatedly decreased the amount of Jewish immigrants entitled to enter Palestine and took away the special benefits they had previously bestowed upon German Jews just at the time when the situation facing those same people steadily worsened (Halamish 2010: 142) Similarly, the United States, Britain and France began to frown upon Jewish emigration to Shanghai at the behest of some of their wealthy citizens living in the open city, which required no documents to land and which received approximately 14,000 Jewish refugees between 1938 and the summer of 1939; it would have closed off its territory sooner albeit for Japanese resistance to Western governments' pressure (Hochstadt 2010: 114-117).

Following just over two years as High Commissioner for German Refugees, McDonald resigned from his post in 1935. McDonald's replacement as High Commissioner, the Briton Sir Neill Malcolm, inherited an even less powerful role than his predecessor (Heim 2010: 29). Nonetheless, Malcolm still managed to bring together 
representatives from fifteen countries in late 1936 for a conference focused on the German refugee question.

States, although publicly supportive of potential measures to alleviate the suffering of German refugees within their territories, remained particularly hesitant to commit to helping potential future arrivals from Germany. Romania noted that it had already reached its capacity for receiving refugees, apart from those travelling through the country. ${ }^{1}$ The Netherlands wanted to retain its power to allow or disallow refugees from entering its territory. Switzerland repeatedly drew attention to the problem of clandestine refugees and underlined the difficulties caused by their continued entry at a time of economic depression, stating its preference to "aid the refugee coming from Germany to settle elsewhere" rather than allow them settle in its territory. ${ }^{2}$ Resembling recent asylum debates, Belgium thought countries should be allowed to ask refugees to return to the country in which they found first asylum. ${ }^{3}$ Nevertheless, in addition to the UK, France, Norway and Denmark, all of the countries named above, except Romania, adopted a provisional 1936 non-binding arrangement set out in the conference with various amendments that bestowed refugee status upon Germans who had arrived in those countries between 1933 and 1936. Further efforts by the High Commissioner for German Refugees to attain states' acquiescence to more authoritative rules defining their treatment of German refugees proved mostly futile, however. Only two countries, the UK and Belgium, ratified the later Convention concerning the Status of Refugees coming from Germany, completed in February 1938 as restrictive measures against rising numbers of refugees from Germany and Austria became more widespread (see Robinson 1953: 3). ${ }^{4}$

Despite their lack of international representation, pro-migrant groups did succeed in mitigating the severity of restrictive migration policies in some countries. In France, for example, substantial sections of the Communist and Socialist Parties, the League of Rights of Man and Citizen, the Catholic Left and several Jewish bodies continued to promote more generous policies, resulting in the Popular Front's slackening of immigration restrictions in 1936 (Caron 1999: 141). In the United Kingdom, pro-asylum opinion in the wake of the November Pogroms in 1938 caused the British government to repeal its restrictive policies brought in after the "Anschluss" in March of the same year (Marfleet 2006: 136). Public protests in Belgium also caused the national government to halt expulsions of Jewish refugees (Caestecker) Moore 2010: 260). In the United States, pro-migrant actors focused enough pressure on the government for President Franklin D. Roosevelt to convene a conference in Evian in July 1938. Indeed, in the months leading up to Evian, several prominent

1 "Inter-Governmental Conference on the Legal Status of Refugee coming from Germany", Second Meeting, 2 July 1936, S.R.A./1st Session/P.V.2., League of Nations archives.

Ibid.

3 Inter-Governmental Conference on the Legal Status of Refugee coming from Germany', Fourth Meeting, 3 July 1936, S.R.A./1st Session/P.V.4, League of Nations archives.

4

France also ratified the convention but this came in 1945. 
Jewish voluntary groups - and Christian voluntary groups, to a lesser extent - came together for a conference to discuss the refugee issue. Almost simultaneously, two prominent Jewish politicians, Emanuel Celler and Samuel Dickstein, publicly raised the subject in the American Congress (Sjoberg 1991: 113). Dorothy Thompson's article in the April 1938 edition of Foreign Affairs gave further vent to the consternation amongst certain organisations surrounding America's failure to try to help find a solution to the European refugee crisis (Thompson 1938; see also Sjoberg 1991: 70-1 and 116).

In July 1938, twenty-nine governments came together in a small French town to discuss the problem of refugees fleeing Nazism. Roosevelt's defined terms for discussion at the Evian conference, which ensured that existing immigration laws remained in place, meant that the conference produced little by way of feasible results to help refugees (Sjoberg 1991: 124). Instead, most of the focus concentrated on how the Jewish exodus had "become so great that it renders racial and religious problems more acute, increases international unrests [sic], and may hinder seriously the process of appeasement in international relations. ${ }^{\prime 5}$ The resolution adapted at Evian also recorded that:

"[T]he involuntary emigration of large numbers of people, of different creeds, economic conditions, professions and trades [...] is disturbing to the general economy, since these persons are obliged to seek refuge, either temporarily or permanently, in other countries at a time when there is serious unemployment." 6

The resolution's negligible recommendations - the highlight involved setting up the Intergovernmental Committee on Refugees, which held few formal competences and reacted cautiously - clearly demonstrated states' reservations in helping refugees escape Nazi persecution. The silent understanding between the Americans and the UK to refrain from raising the subject of migration to Palestine merely confirmed this (Halamish 2010: 131). Thirty-nine private voluntary organisations (PVOs) [similar to modern-day NGOs], including twenty-one Jewish groups, had attended the conference in an unofficial capacity. Four different opinions resonated amongst PVOs: (i) to encourage Jews to emigrate to Palestine by lifting the contemporary quotas; (ii) to integrate refugees in their present environment; (iii) to settle Jewish refugees in an as yet uninhabited location; and (iv) to guarantee Jews minority rights in their new countries of asylum. ${ }^{7}$ The disjointed tactics of PVOs meant that their voice remained weak and disjointed. In Michael Marrus's (1985: 170-2) words, "Evian simply underscored the unwillingness of the Western countries to receive

5 Resolution adopted by the Intergovernmental Committee (Evian) on July $14^{\text {th }}, 1938$. Published in League of Nations Official Journal, Vol. 19, 1938: 676-677. Ibid.

7 "Report for the sub-committee for the reception of organisations concerned with the relief of political refugees coming from Germany including Austria", 13 July 1938, S543, League of Nations archives. 
unwanted Jewish refugees" with "one delegate after another read[ing] statements into the record, justifying existing restrictive policies and congratulating themselves on how much had already been accomplished for refugees." As Caestecker and Moore (2010: 319) have demonstrated, immigration remained a domestic rather than an international issue in the wake of Evian. Soon after the conference, Hungary and Yugoslavia closed their frontiers, Italy announced its 1938 anti-Jewish decrees, and Holland, Belgium and Switzerland reinforced their borders to restrict the entry of refugees (Marrus 1985: 169).

Events in Austria and Germany from March to November 1938 turned, in the words of Claudena Skran (1995: 53), “a manageable refugee flow into an uncontrollable flood". Despite an outcry in West European public and media opinion, most governments intensified their external controls through visa issuing facilities and border controls (Caestecker/Moore 2010: 274 and 277). This partly resulted from the 1938 Nazi laws forbidding Jews fleeing from taking their belongings and savings. Previously, Jews brought certain economic advantages to host states because they managed to arrive with some of their resources from Germany but from 1938 onwards Jews frequently arrived penniless at a time of continuing economic depression.

Between early 1936 and mid 1938, private organisations and individuals drew the High Commissioner's attention to approximately 5,000 cases where German refugees received expulsion orders from countries of asylum, leading to the High Commissioner's intervention to halt "unauthorised measures of expulsion taken by the police or minor officials". ${ }^{8}$ But the cessation of the High Commissioner's office on 1 January 1939 closed this avenue off despite the marked augmentation of refugees fleeing Nazism and by then Fascist Spain. By the outbreak of war in September 1939, the number of people who escaped Nazism since 1933 had increased to $400,000 .^{9}$ More would have left except for the increasingly restrictive immigration policies of European countries caused by anti-Semitism, labour shortages and refugees' destitution in the crisis-hit 1930s.

\subsection{Migration management during post-war crises}

The end of the Second World War instigated several crucial developments. Countries vowed to make sure the newly formed United Nations would serve the world better than the League of Nations. The Charter of the United Nations, signed in 1945, insured, cemented and enhanced the role of private voluntary organisations; these organisations then became known as non-governmental organisations

8 Neill Malcolm, "Refugees coming from Germany", 22 Aug 1938, A.25.1938.XII, League of Nations archives.

9 League of Nations, "International Assistance to Refugees: Supplementary Report to the Twentieth Assembly by Sir Herbert Emerson" (20 Oct. 1939), p. 2. Contained in Fonds UNHCR 5, "Personal Papers of Gustave G. Kullmann, Box 6. Its report recorded that 225,000 Jews fled from Germany, 134,000 Jews from Austria and Bohemia-Moravia, and 40,000 non-Jews from both. See also Skran 1995: 54. 
(NGOs) to distinguish them from the various UN bodies. By stipulating that the UN could "make suitable arrangements for consultation with non-governmental organisations which are concerned with matters within its competence" they ensured the presence of NGOs in significant political discussions - a development that has had consequences for more recent migration debates, as will be outlined towards the end of this article. ${ }^{10}$

Exclusive measures towards immigrants could not be maintained in the wake of the Second World War because of the incredible population loss that the carnage had inflicted - approximately 36.5 million people died on the continent from war-related causes (Judt 2005: 17). Furthermore, Western Europe needed to rebuild since approximately $40 \%$ of German housing, $30 \%$ of British housing and $20 \%$ of French housing had been destroyed during the war (Judt 2005: 82). Western Europe needed labour, especially when the European economy began to take off once again in the 1950s. Here the European countries took different approaches in shaping the emerging migration regimes. Those regimes were deeply rooted in the history of each single country: while countries with strong colonial ties mixed their minority policies with their migrant policies, countries such as Germany and Austria developed a new system that enabled the recruitment and rotation of workers from abroad. Other countries, such as the Netherlands and Belgium, adopted mixed forms of migration regulations.

Millions of people, who came predominantly from rural backgrounds, migrated from countries located on the periphery of Western European to the core of Western Europe to help the post-war expansion. Seven million left Italy between 1945 and 1970, a quarter of Greece's population of working age departed between 1950 and 1970, and 1.5 million Portuguese migrated between 1961 and 1974 (Judt 2005: 334). West Germany, Switzerland, the Benelux countries and France were the main receivers, with the UK also welcoming approximately half a million Irish migrants from 1945 to 1961 (Keogh 1994: 164 and 215). Nevertheless, this failed to meet labour demands in the host states, which began instead to look beyond Western Europe for migrant labour. The United Kingdom, France, the Netherlands and Belgium received large numbers of migrants from their colonies, while Western Germany recruited significant numbers of Turks and Yugoslavs, as well as other nationalities from Southern European and Northern-African states, under the Gastarbeiter scheme. National and local administrative bodies in many Western European countries continued to believe migrants were temporary and would depart if work opportunities decreased. For that same reason, they saw no need to invest in infrastructure such as social housing, schools and medical care for their enlarged populations (Berlinghoff 2009: 185). When the number of immigrants began to place substantial pressures on social services and the economy of Western European countries in the early 1970s began to stagnate, demands for foreign labour slowed. In 1972 Denmark declared a recruitment ban for all non EEC and Scandinavian countries. In 1973 the UK implemented its Immigration Act and Western Germany stopped any further

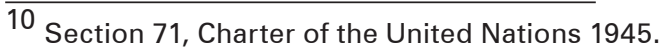


recruitment. The following year, both Belgium and the Netherlands tightened their immigration policies and France declared a halt to immigration (Berlinghoff 2009: 189; see also Hansen 2003: 27). At around the same time, 1973 oil price shock resulted in serious economic recession throughout Western Europe. By then, West Germany had approximately 2.8 million foreign workers, France held 2.3 million immigrant workers, and Great Britain contained almost 2 million immigrants from the Commonwealth (Judt 2005: 335-6).

\subsection{0s-1980s: European Commission vs. European states}

During the 1950s and 1960s, Western Europe reached almost full employment (Judt 2005: 332). Labour relations problems in Western Europe and a notable rise in commodity prices did, however, result in accelerated inflation in the late 1960s and early 1970s (Mazower 1998: 334). Following the demise of the Bretton Woods system in 1971, partly as a result of the U.S. government's need to finance its role in the Vietnam War, and the 1973 oil price shock, a recession-hit Western Europe saw unemployment rise considerably throughout the 1970s. France's unemployment rate went from $2.6 \%$ in 1971 to $7 \%$ by the end of the decade. The UK rate rose from $3.6 \%$ to $9 \%$ in the same period. Although German unemployment failed to reach such scales, it too suffered a notable rise (Judt 2005: 456-7; see also Cameron 2001: 8-9).

Despite attempts by many Western European countries to limit the in-flow of migrant workers from the early 1970s onwards, the reunification of families with those already in situ meant that unwanted migration continued at a steady pace. Many countries' constitutions formed after the Second World had extended rights to nationals and non-nationals alike, which led to a noticeable increase in cases involving immigrants brought before the courts challenging restrictive changes in the 1970s (Guiraudon 1997: 234). As Joppke (1998: 271) has convincingly argued, the growth of inherently liberal principles in many western states throughout the second half of the twentieth century made it increasingly difficult for Western European governments to exercise complete control over unwanted migration. Developments at the European Commission stemmed government actions even further.

The 1957 Treaty of Rome stated that "freedom of movement for workers shall be secured within the Community" and that this would "entail the abolition of any state discrimination based on nationality between workers of the Member States as regards employment, remuneration and other conditions of work and employment". ${ }^{11}$ Although this only applied to European member citizens (cf. Oliver 1985: 62), the European Commission began to take a further interest in conditions facing all immigrants - from member states and elsewhere - from the early 1970s onwards because of the obvious social issues emerging as a result of the sizeable immigrant communities in many member states. Soon after the 1973 oil shock, the European Commission published its social action programme. One objective was to achieve

${ }^{11}$ Article 48 (1) and 48 (2), Treaty of Rome. 
"an equality in living and working conditions" for "all migrant workers and their families, whether they come from the countries of the Community" or "whether legally admitted from third countries" (Commission of the European Communities 1974: 23). The Commission felt that:

"The migration population live and work in conditions substantially inferior to those of the indigenous population. Discrimination against migrant workers exists in various forms throughout the Community, in such matters as social security, housing and rights to participate at different levels of decision making (ibid)."

In the Commission's opinion, there was "an urgent need for the Community to assume its overall human responsibilities towards the whole migrant population, irrespective of its country of origin". It felt that this could only be achieved by developing "an overall approach to coordinate different aspects" (ibid). Later that same year, it proposed an action programme in favour of migrant workers and their families. In it, the Commission criticised member states' treatment of third country migrants even more explicitly and voiced its aim to "move towards concertation of immigration policies". While migrants coming from other member states acquired many of the same rights as those of indigenous workers under Community legislation, third country migrants:

"[...] do not have the right to freely enter the territory of the host country for the exercise of employment; they are required to possess a work permit and are subject to administrative controls [ ...] Third country migrants are liable to deportation, too often at the discretion of the host country authorities." (Commission of the European Communities 1976: 14)

Again, the Commission's suggestion to tackle this problem revolved around the aim of "adopting a common strategy to meet the problem (ibid)."

When Western European states, acting through the forum of the European Council, took note of the Commission's proposals in its resolution of 9 February 1976, they failed to outline whether or not member states should consult each other over the issue of providing rights for third country migrants. By contrast, when the Council discussed the subject of clandestine immigration, it considered it "important to strengthen cooperation between Member States in the campaign against illegal immigration of workers who are nationals of third countries". The Council also sought to "undertake appropriate consultations on migration policies vis à vis third countries" (Council of the European Communities 1976: 8). This split in inclination of European member states to confer with one another over matters of prohibition, whilst avoiding consultation with regard to the treatment of immigrants within member states, was a sign of things to come.

Despite attempts by West European countries to stem immigration, migration continued to grow, mainly due to family reunification. The late 1970s saw parties variously labelled "extreme right-wing", "populist" and "anti-immigrant" parties in Europe start to become increasingly prominent (Agnazi 1995; Gibson 2002). Halting immigration became one of the most central tenets of many of these parties' 
manifestos. The large increases in the number of people migrating to Europe and governments' perceived weaknesses in adapting their policies to cope with this upsurge served to bestow anti-immigrant political parties with a seemingly legitimate target to communicate their message. With immigrants sometimes entitled to welfare provisions and housing at a time of increasing financial insecurity, political, media and public hostility towards immigrants rose. As a consequence, these parties' anti-immigrant stance began to find resonance with voters, coinciding as it did with a decline in traditional political parties' ability to address the needs of some of their electorate (Mair 2006). Serious cleavages began to develop amongst more traditional political parties. Indeed, one of the factors that made immigration and asylum so difficult to analyse was that voters from sometimes very different political backgrounds could change parties because of their strong stances on such issues. As Paul Sniderman et al. (2000: 13) recorded, when issues relating to immigration moved to the centre of political argument, "the animating values of the right resonate[d] not only with its own adherents but also with a very large portion of the adherents of the left".

In an attempt to allay this trend, established political parties in Western Europe reacted in a number of ways; with varying degrees of success. In some countries, they attempted to retain, or attract back, their traditional voters by adapting and reshaping many of the ideas put forward by these anti-immigration parties and selling them as their own. In the run-up to the 1979 general election in the UK, for instance, Margaret Thatcher's Conservative party successfully adopted some of the increasingly popular British National Front's policies to stem the flow of voters (Messina 1987: 419-420). Conversely, in some countries conventional political parties attempted to ignore or isolate these anti-immigration parties. This met with mixed results in states such as Belgium and West Germany (Schain/Zolberg/Hossay 2002). If the established parties ignored or cut off anti-immigrant parties, they risked enabling those same parties to attain a foothold in the political system by gaining the protest votes of people frustrated with the more regular parties. With the acquisition of a certain number of representative seats, anti-immigrant parties had the potential to expand their vote because of the high-profile nature of their new positions in society and the structural benefits that came their way on obtaining office.

Reacting to the notable rise in racism in Europe throughout the late 1970s and early 1980s, the European Commission and the European Parliament made various calls to act on immigration, including the 1977 Joint Declaration on Fundamental Rights, which affirmed respect for the 1950 European Convention on Human Rights. But Andrew Geddes (2000: 54) fittingly commented that "as with many EU denunciations of racism and xenophobia, the declaration was essentially symbolic and not backed by attribution of competence to act". By the mid 1980s, the Commission felt that a community migration policy had become all the more necessary and consequently put forward a set of guidelines for such a policy in which it highlighted some of the problems associated with immigration:

"A number of Member States had to face similar problems: inadequate social education infrastructure and housing shortages as migrant families 
were increasingly reunited, difficulties in cultural assimilation, uneasy relationships between the national and foreign communities, and potential competition on the labour market." (European Commission 1985: 6)

Many of the recommendations contained foresight and appeared to include a genuine wish to help migrants to enjoy a better standard of living in society. For example, the Commission aimed to "provide members of their [migrants'] families residing in the Community with the same protection in the field of social security as Community nationals" because "workers in the same objective situation cannot be treated differently on the sole basis of nationality" (ibid: 14). In July 1985, the Council endorsed these proposals but when the Commission attempted to go further by setting up a prior communication procedure on migration policies, West Germany, France, the Netherlands, Denmark and the UK opposed such developments. The Commission had asked the member states to provide it with "draft measures they inten[ded] to take with regard to third country workers and members of their families, in the areas of entry, residence and employment", along with "the texts of provisions laid down by law, regulation or administrative action already in force, and also the texts of agreements made with third countries" (ibid: 19-20). Brussels wanted to "facilitate the adoption of a common position ... particularly as regards international instruments relating to migration". For many Western European governments, it was a step too far: the Commission had exceeded its strictures.

West Germany, France, the Netherlands, Denmark and the UK proceeded to make submissions to the European Court of Justice against the Commission, arguing that the Treaty of Rome had made no provision for a common policy in the social field and that the Commission's role was designated to exclusively deal with nonbinding instruments (Simmonds 1988: 182-3). At the oral procedure stage of the court hearing, the Commission communicated its past problems with the member states regarding a common migration policy (Simmonds 1988: 197). The European Court of Justice annulled certain parts of the Commission's policy initiative, with the overall effect of fudging the issue. What the case did show, however, was the intent of many West European states to keep the Commission, which had shown itself to be in favour of integrating unwanted migrants into European societies, away from an issue that they saw as something for states alone to contemplate. Various governments considered the Commission's attempt to dictate member states' social policies as an attack on their sovereignty. In response, European justice and interior ministers created an Ad Hoc Group on Immigration (AHI) in 1986. Critically, this was an intergovernmental body set up on an intergovernmental initiative with little Commission involvement.

Another almost simultaneous inter-governmental initiative, the Schengen Agreement, also had a significant affect on immigration policy in Western Europe. The aim of the first Schengen Agreement, signed in June 1985 by the Benelux countries, France and Germany, aimed to gradually decrease controls on community citizens crossing internal borders having originated as a reaction to roadblocks set up by truck drivers irritated by the long delays they experienced when passing between the Franco-German borders (Lahav 2004: 42). The intention of the second Schengen Agreement, signed in 1990, bore little resemblance to the first. As Sandra Lavenex 
(2001: 95) explained, "the biggest consensus among the contracting parties was manifested in questions relating to the fight against illegal immigration and the intake of asylum seekers, which was in fact where the most detailed and far-reaching provisions were adopted - although the question of asylum seekers and refugees was not even mentioned in Schengen I." With these changes, Schengen came to signify for many critics "Fortress Europe" due to the inclusion of a number of measures relating to the harmonisation of regulations concerning checks at external frontiers, the improvement of international co-operation at the level of the police and judiciary and the harmonization of visa and immigration policies. Julian Schutte (1991: 550) has pointed out that "the most spectacular novelty" was the creation of a set of common automated data relating to wanted persons called the Schengen Information System "to help with the maintenance of public order and security, and the enforcement of the laws on the control of aliens" (Schutte 1991: 559). The 1987 Single European Act (SEA) and the 1992 Maastricht Treaty confirmed these objectives and it became clear that Western European countries had to create a more common strategy for migration.

Just as European countries appeared to gain a grip on achieving a consensus to control economic migrants attempting to gain access to the EU, another phenomenon emerged. Between 1985 and 1994, over 3.4 million people (Eurostat: 1996) made asylum applications in the EU as a result of increasing international conflicts (the break-up of Yugoslavia, in particular), the fall of the Berlin Wall in 1989 and the subsequent collapse of the Soviet regime. As economic migrants found it more difficult to enter Western Europe, some potential migrants also looked to asylum as a way of facilitating entry to the EU. In an attempt to regulate this in-flow, European immigration ministers adopted the Dublin Convention in 1990 to eradicate so-called "asylum-shopping" by ensuring that an asylum seeker could only make an application in his/her country of arrival.

\section{The international community's attitude to migration during the present crisis}

In the 1990s, European member states' tendency to remove the possibility of Commission tinkering with national immigration and asylum policies for non-EU citizens continued, with immigration and asylum too politically explosive for most countries' governments to give up national competency (Hatton/Williamson 2004b: 25, 32). Instead, inter-governmental working groups, comprised of ministers from various member states with responsibility for immigration, brought forward several initiatives. Virginie Guiraudon (2000: 251) acutely surmised the idea behind these moves:

“Building upon pre-existing policy settings and developing new policy frames, governments have circumvented national constraints on migration control by creating transnational co-operation mechanisms dominated by law and order officials, with EU institutions playing a minor role. European trans-governmental working groups have avoided judicial scrutiny, elimi- 
nating other national adversaries and enlisted the help of transnational actors such as transit countries and carriers."

Although intra-national discussions on migration in Europe began in the 1980s and continued to gather apace throughout the 1990s, the 2000s marked the reintegration of asylum and third country migration policies into the domain of the European Commission. The 1999 European Council meeting at Tampere signalled the beginning of the end of the differences between the Commission and the member states concerning asylum and migration policy. Significantly, member states allowed migration to return to the European Commission domain only after it had become firmly established under the responsibility of the EU's third pillar, which represented security and justice affairs, rather than under the directorate-general representing employment, social affairs and equal opportunities (Guiraudon 2000; Costello 2003). This meant that notions of security continually tended to supersede notions of migrants' rights. As a result, the European Commission had lost its long battle to moderate West European countries' asylum and immigrant policies, with the member states' more restrictionist views firmly winning out. To defend their immigration policies throughout the 2000s, West European states fashioned arguments based on principles relating to European sovereignty, the integrity of welfare regimes and public security. In contrast to European Commission efforts to counter member states' more parsimonious measures in the 1970s and 1980s, the European Commission in the 2000s facilitated West European states' policies by joining together with the European Council to help externalise and securitize European asylum and migration policies - particularly after 9-11 - in an attempt to stem the flow of unwanted migrants (Lavenex 2006: 334; cf Neal 2009). This became more obvious throughout the 2000s. In 2004, for instance, Italy began returning thousands of migrants to Libya that it had intercepted en route to its territory (Paoletti 2011: 275). Pro-migrant NGOs, such as Medicins sans Frontieres, and the UNHCR, denounced Italy's move, pointing out that the state had repatriated migrants without offering them clear access to proper asylum procedures. They also highlighted Libya's continuing failure to sign the UN Refugee Convention (Corriere della Serra 2004; La Stampa 2004b). The Italian government countered these criticisms by maintaining that its actions corresponded to all national and international norms. Crucially, the European Commission - in contrast to the European Parliament and the Council of Europe - mutely supported the Italian government's measures (La Stampa 2004a).

The model of lightly regulated financial capitalism that emerged over the past three decades resulted, in 2008, in the worst international economic downturn since the 1930s. The consequences of the global financial crisis, variously referred to by leading economists as the Great Recession (e,g, Stiglitz 2010: xi) and the Lesser Depression (Krugman 2011), have largely continued to affect Western Europe unabated since then, with the ongoing Euro crisis not yet showing any signs of ending. A past European Commission (1997: 1) survey on racism and xenophobia concluded that people dissatisfied with their life circumstances, who feared unemployment, remained insecure about their futures and held little confidence in public authorities were most likely to support xenophobic views. Amid rising unemployment, mount- 
ing public dissatisfaction with governments, and unsustainable state debts causing uncertainty about what the future holds, the conditions outlined in the European Commission survey are growing throughout Western Europe, particularly along the western (Ireland and the UK), southern (Greece, Portugal, Italy and Spain) and northern (Denmark and Finland) periphery. This has led many West European states to discuss enforcing their residence laws more strictly, improving their border management and boosting their return programmes (Frontex 2009: 4).

As the IOM (2010: 4) has noted, the situation facing migrants, and especially non-EU migrants, has deteriorated more rapidly than that of natives during the crisis. Migrants employed in low-skilled sectors especially affected by the economic recession, such as the construction industry and the services sector, have been particularly badly hit by unemployment since 2008 (Beets/Willekens 2009). Somewhat predictably, many migrants previously required by West European countries to help drive their economies forward have now become unwanted - just as occurred during the 1970s with guest worker migrants. As the 1970s and early 1980 s demonstrated, however, migrants do not always leave countries after the onset of economic problems, despite official desires for them to do so. The same is true for the current crisis, especially with regard to non-EU migrants, who may desist leaving for fear that they will face barriers in the future if they want to return (IOM 2010: 4). It is still too soon to know whether public opinion about immigration in Western Europe is uniformly turning more hostile as different national situations have so far led to different results (IOM 2010: 5-6). Nonetheless, an analysis of attitudes in Western Europe to immigrants and minorities during past crises provides some unpleasant indicators of what can happen during times of severe economic difficulty.

De Bromhead, Eichengreen and O'Rourke (2012: 5), in their analysis of right-wing political extremism during the Great Depression, have highlighted how economic hard times can boost such ideologies in countries containing sizeable immigrant populations. Crucially for the study of the current crisis, they found that it was only when a contraction persisted for a number of years that noticeable trends arose. They argued that political polarization during the late 1920s and 1930s occurred in countries that had relatively recent histories of democracy, that had existing rightwing extremist parties, and that had electoral systems with low barriers for new parties to overcome to achieve parliamentary representation. Most significantly, however, they considered that the rise of right-wing political extremism during the Depression was most profound where depressed economic conditions were allowed to persist (de Bromhead/Eichengreen/O'Rourke 2012: 25). In relation to the 1970s and beyond, an empirical analysis of voting attitudes from 1970 to 2002 in OECD countries argued that a one-percentage-point decline in per capita GDP growth led to a one-percentage-point increase in the vote share for right-wing or nationalist parties (Brückner/Grüner 2010). Interestingly, the same authors found that extreme left-wing and communist parties did not tend to benefit as much from economic downturns as their right-wing counterparts.

Whilst some of the southern peripheral West European countries most affected by the current crisis have had chequered histories of democracy until the 1970s, they have all since established progressive, liberal democracies that show no sign, 
as yet, of falling apart. Despite generally low thresholds for new parties aiming to emerge on the political scene, these same states do not yet host well-established extreme right-wing anti-immigrant political parties (apart from Italy). As Art (2011: 3) notes, the radical right in Western Europe has experienced almost as much failure establishing itself as success. It is difficult at this stage, therefore, to see how these types of organisations could come to national prominence in the West European countries currently most affected by the crisis although recent developments in Greece look ominous. Perhaps former Communist countries in Central and Eastern Europe, such as Hungary today, will provide extreme right-wing parties with more viable options for success in the future; although these countries' lack of exposure to extensive immigration may offset the build-up of explicitly anti-immigrant parties. For those West European countries where right-wing anti-immigration parties are already well established, such as France, Belgium, the Netherlands, Finland, Denmark, Italy and Austria, the economic difficulties may enable these parties to further increase their popularity. As Fukuyama (2012: 53) records, populism in the aftermath of the financial crisis has taken a distinctly right-wing form rather than a left-wing form, an occurrence he explains away by highlighting the current dearth of intellectual ideas on the Left.

The repercussions of the economic crisis have already seen some politicians in Western Europe target migrants and minorities to demonstrate their resoluteness on rules and regulations. Unfortunately, migrants and minorities today cannot rely on the European Commission to challenge states' hard-line positions or actions because its own rules often facilitate states' moves. When Italian authorities began fingerprinting Roma living in camps throughout the country in 2008 the European Commission, in contrast to vocal criticism from the European Parliament, quietly endorsed Italy's plans, as the actions acceded to the Commission's own rules on security (Times 2008). The European Commissioner, Viviane Redding, appeared to counter this trend when she vocally and scathingly criticised France's deportation of Romanian and Bulgarian Roma in the summer of 2010. She had to later refrain from taking legal action against France, however, when it became clear that the country had acted within the legal parameters afforded by the EU's own 2004 directive on free movement of EU citizens, which had allowed France to deport the Roma on security grounds (Parker 2012). In many ways, this symbolised the European Commission's torn role; although it wanted to continue to act in its traditional role of safeguarding migrants' rights against European states' actions, it found itself increasingly hamstrung by the new, more restrictive parameters it had to work within.

\section{Conclusion}

This paper has highlighted how the influence of IGOs in migrant affairs in Western Europe has increased substantially since the 1930s. Nonetheless, as has been outlined, this change has come at a significant price. The European Commission, currently the most powerful international broker in affecting migration policies in 
Western Europe, has had to adopt a much less critical role of states' restrictive practices during the present crisis than its predecessors in Brussels in the 1970s and the League of Nations High Commissioner for Refugees in the 1930s. The European Commission today has to promote migration policies that often complement rather than challenge member states' unsympathetic practices. Nonetheless, unwanted migrants in Western European states today are, despite this change, still likely to receive access to a host of rights that their forerunners, especially in the 1930s, had to do without. This has derived as a result of the "liberalness of liberal states" (Joppke 1998: 292) and pro-migrant actors' increased success in offering support and advocacy for such people. In the 1930s, national and international voluntary organisations sympathetic to the plight of unwanted migrants objected to governments' increasingly discriminatory practices. But these voluntary organisations had no avenues to seriously challenge governments' actions and frequently campaigned for diverging goals (at Evian, for instance, private organisations sought four markedly different solutions, as outlined above). The additional political space opened up by the end of the Cold War and the major UN impetus to include civil society from the early 1990s onwards allowed NGOs to engage in political debate about issues such as migration; a development the explosion in global communications further enabled (We/ch 2001: 3). Moreover, networking between different migrant organisations ensured increased power (Kjaerum 2003: 207). By referencing humanitarian ideals, national commitments to human rights and the rule of law (Epp 1998), promigrant actors have managed to seriously hinder and obstruct Western European governments' moves against unwanted migrants, resulting in a large gap remaining between policies formed and policies implemented. As a result, Western European states have so far failed to extol the same control over unwanted migrants who have managed to reach their countries as occurred in the 1930 s.

\section{References}

Agnazi, Piero 1995: The Re-emergence of Extreme Right-Wing Parties in Europe. Wien: Institut für Höhere Studien: 1-10.

Arendt, Hannah 2004: The Origins of Totalitarianism. New York: Schocken Books.

Art, David 2011: Inside the Radical Right: The Development of Anti-Immigrant Parties in Western Europe. Cambridge: Cambridge University Press.

Beck, Robert 1999: Britain and the 1933 Refugee Convention: National or State Sovereignty? In: International Journal of Refugee Law 11,4: 597-624.

Beets, Gijs; Willekens, Frans 2009: The global economic crisis and international migration: An uncertain outlook. In: Vienna Yearbook of Population Research 7,1: 19-37. [doi: 10.1553/populationyearbook2009s19].

Berlinghoff, Marce/ 2009: Between Emancipation and Defence: The failure of the Commission's attempt to concert a Common European Immigration Policy. In: L’Europe en Formation 3: 353-354, 183-195. [doi: 10.3917/eufor.353.0183].

Bierman Jr, Harold 2010: Beating the Bear: Lessons from the 1929 Crash Applied to Today's World. Westport, CT: Praegar. 
Boswell, Christina 2007: Migration control in Europe after 9/11: Explaining the absence of securitization. In: Journal of Common Market Studies 45,3: 589-610.

Brückner, Markus; Grüner, Hans Peter 2010: The OECD's growth prospects and political extremism. In: Vox. Accessed at http://www.voxeu.org/index.php?q=node/5047. NOTE: This short article is a summary of their CEPR Discussion Paper (No. 7723), 2010: Economic Growth and the Rise of Political Extremism: Theory and Evidence.

Caestecker, Frank; Moore, Bob 2010: Refugees from Nazi Germany and the Liberal European States. Oxford: Bergahn.

Cameron, David 2001: Unemployment, Job Creation, and Economic and Monetary Union. In: Bermeo, Nancy (Eds.): Unemployment in the new Europe. Cambridge: Cambridge University Press, 7-51.

Caron, Vicki 1999: Uneasy Asylum: France and the Jewish Refugee Crisis, 1933-1942. Stanford: Stanford University Press.

Collyer, Michael 2005: Secret Agents: Anarchists, Islamists and Responses to Politically Active Refugees in London. In: Ethnic and Racial Studies 28,2: 278-303.

Commission of the European Communities 1974: Social Action Programme. In: Bulletin of the European Communities, Supplement 2/74.

Commission of the European Communities 1976: Action programme in favour of migrant workers. Transmitted by the Commission to the Council on 18 December 1974. In: Bulletin of the European Communities, Supplement 3/76: 10-22.

Corriere della Sera 2004: Rimpatri forzati in Libia, ma gli sbarchi continuano, 03.10.2004.

Costello, Cathryn 2003: EU Asylum Law and Policy. In: Fraser, Una; Harvey, Colin (Eds.): Sanctuary in Ireland: Perspectives on Asylum Law and Policy. Dublin: IPA, 18-50.

Council of the European Communities 1976: Council resolution of 9 February 1976 on an action programme for migrant workers and members of their families. In: Bulletin of the European Communities, Supplement 3/76: 7-8.

de Bromhead, Alan; Eichengreen, Barry; O'Rourke, Kevin H. 2012: Right Wing Political Extremism in the Great Depression. In: University of Oxford Discussion Papers in Economic and Social History.

Epp, Charles 1998: The rights revolution: lawyers, activists, and supreme courts in comparative perspective. Chicago: University of Chicago Press.

European Commission 1985: Guidelines for a Community policy on migration. In: Bulletin of the European Communities, Supplement 9/85: 6.

European Commission 1985: Commission decision of 8 July 1985. In: Bulletin of the European Communities, Supplement 9/85: 19-20.

European Commission 1997: Eurobarometer Opinion Poll no. 47.1: Racism and Xenophobia in Europe.

Eurostat 1996. Asylum-seekers in Europe 1985-1995. In: Statistics in Focus.

Frontex 2009: The impact of the global economic crisis on illegal migration to the EU. Warsaw: Frontex. http://www.europarl.europa.eu/meetdocs/2009 2014/documents/ libe/dv/frontex_/frontex_en.pdf.

Fukuyama, Francis 2012: The Future of History. Can Liberal Democracy Survive the Destruction of the Middle Class? In: Foreign Affairs 91,1: 53-61.

Geddes, Andrew 2000: Immigration and European integration: towards fortress Europe? Manchester: Manchester University Press. 
Gibson, Rache/ 2002: The Growth of Anti-Immigrant Parties in Western Europe. New York: Edwin Mellen.

Guiraudon, Virginie 2000: European Integration and Migration Policy: Vertical Policymaking as Venue Shopping. In: Journal of Common Market Studies 38,2: 251-271.

Guiraudon, Virginie 1997: Policy Changes Behind Gilded Door: Explaining the Evolution of Aliens' Rights in Contemporary Western Europe, 1974-1994. Cambridge, MA: Harvard (PhD). [doi: 10.1111/1468-5965.00219].

Haddad, Emma 2008: The External Dimension of EU Refugee Policy: A New Approach to Asylum? In: Government and Opposition 43,2: 190-205. [doi: 10.1111/j.14777053.2007.00250.x]

Halamish, Aviva 2010: Palestine as a Destination for Jewish Immigrants and Refugees from Nazi Germany. In: Caestecker, Frank; Moore Bob (Eds.): Refugees from Nazi Germany and the Liberal European States. Oxford: Bergahn: 122-150.

Hammer, Tomas 1985: European immigration policy: a comparative study. Cambridge: Cambridge University Press.

Hansen, Randall 2003: Migration to Europe since 1945: Its History and its Lessons. In: The Political Quarterly 74: 25-38. [doi: 10.1111/j.1467-923X.2003.00579.x].

Hatton, Timothy; Williamson, Jeffrey 1998: The Age of Mass Migration: Causes and Economic Impact. New York: Oxford University Press.

Hatton, Timothy; Williamson, Jeffrey 2004a: International Migration in the Long-run. Positive Selection, Negative Selection and Policy. National Bureau of Economic Research: Harvard Working Paper 10529, 2004.

Hatton, Timothy; Williamson, Jeffrey 2004b: Refugees, Asylum Seekers and Policy in Europe, National Bureau of Economic Research Working Paper Series. URL: http:// www.nber.org/papers/w10680, 12.08.11.

Hathaway, James 2005: The Rights of Refugees under International Law. Cambridge: Cambridge University Press.

Heim, Susanne 2010: International Refugee Policy and Jewish Immigration under the Shadow of National Socialism. In: Caestecker, Frank; Moore Bob (Eds.): Refugees from Nazi Germany and the Liberal European States.Oxford: Bergahn: 17-47.

Hobsbawm, Eric 1992: Nations and Nationalism since 1780: Programme, Myth, Reality. Cambridge: Cambridge University Press.

Hochstadt, Steve 2010: Shanghai: A Last Resort for Desperate Jews. In: Caestecker, Frank; Moore Bob (Eds.): Refugees from Nazi Germany and the Liberal European States.Oxford: Bergahn: 109-121.

Human Rights Watch 2009: Pushed Back, Pushed Around. Italy's Forced Return of Boat Migrants and Asylum Seekers, Libya's Mistreatment of Migrants and Asylum Seekers. New York: HRW.

Huysmans, Jef 2000: The European Union and the Securitization of Migration. In: Journal of Common Market Studies 38,5: 751-777. [doi: 10.1111/1468-5965.00263]

IOM (International Organization for Migration) 2010: Migration and the Economic Crisis in the European Union: Implications for Policy. Brussels: IOM.

Jacobson, David 1996: Rights across borders. Immigration and the Decline of Citizenship. Baltimore: John Hopkins University Press.

Jaeger, Gilbert 1999: La Protection Internationale des Réfugiés. In: Institut d'études européennes Documents 12, Louvain-la-Neuve: Université Catholique de Louvain. 
Joppke, Christian 1998: Why Liberal States Accept Unwanted Immigration. In: World Politics 50,2: 266-293.

Judt, Tony 2005: Postwar. A History of Europe since 1945. London: Heinemann.

Keogh, Dermot 1994: Twentieth-century Ireland: nation and state. Dublin: Gill and Macmillan.

Kjaerum, Morton 2003: Human Rights Organisations and the Formation of Refugees Regimes. In: Joly, Danielle (Eds.): Global Changes in Asylum Regimes. Gordonsville, VA: Palgrave Macmillan: 204-14.

Kolchin, Peter 1982: Comparing American History. In: Reviews in American History 10,4: 64-81.

Krugman, Paul 2011: The Lesser Depression. In: The New York Times, 21.07.2011.

Lahav, Gallya 2004: Immigration and Politics in the New Europe: Reinventing Borders. Cambridge: Cambridge University Press.

La Repubblica 2009: Migranti:clandestinio richiedenti asilo? La Ue vuole notizie sul respingimento, 31.08.2009.

La Stampa 2004a: A Bruxelles un documento sui flussi migratori. II commissario Ue: I'Italia ha fatto sforzi eroici "Si' ai centri d'accoglienza nei Paesi del Nord Africa, serve una strategia comune", 05.10.2004.

La Stampa 2004b: "Salvaguardare il diritto d'asilo." Boldrini: va rispettata la convenzione di Ginevra Gran parte dei Paesi nordafricani non lo fanno, 19.10.2004.

Lavenex, Sandra 2001: The Europeanisation of Refugee Policies: Between Human Rights and Internal Security. Aldershot: Ashgate.

Lavenex, Sandra 2006: Shifting Up and Out: The Foreign Policy of European Immigration Control In: West European Politics 29,2: 329-350. [doi: 10.1080/01402380500512684].

Lucassen, Jan; Lucassen, Leo 2009: The Mobility Transition Revisited, 1500-1900: What The Case of Europe Can Offer to Global History. In: The Journal Of Global History 4,3: 347-377. [doi: http://dx.doi.org/10.1017/S174002280999012X].

Mair, Peter 2006: Polity-scepticism, party failings, and the challenge to European democracy. Wassenaar: NIAS.

Marfleet, Philip 2006: Refugees in a Global Era. Basingstoke: Palgrave Macmillan.

Marrus, Michael 1985: The Unwanted. European refugees in the twentieth century. Oxford \& New York: Oxford University Press.

Mazower, Mark 1998: Dark Continent. Europe's Twentieth Century. London: Allen Lane.

McKeown, Adam 2004: Global Migration, 1846-1940. In: Journal of World History 15,2: 155-189. [doi: 10.1353/jwh.2004.0026].

Messina, Anthony 1987: Postwar Protest Movements in Britain: A Challenge to Parties. In: The Review of Politics 49,3: 410-428.

Neal, Andrew 2009: Securitization and Risk at the EU Border: The Origins of FRONTEX. In: Journal of Common Market Studies 47,2: 333-356. [doi: 10.1111/j.14685965.2009.00807.x].

Oliver, Peter 1985: Non-Community Nationals and the Treaty of Rome. In: Yearbook of European Law 5,1: 57-92.

Paoletti, Emanuela 2011: Power Relations and International Migration: The Case of Italy and Libya. In: Political Studies 59: 269-289. [doi: 10.1111/j.1467-9248.2010.00849.x]. 
Parker, Owen 2012: Roma and the Politics of EU Citizenship in France: Everyday Security and Resistance. In: Journal of Common Market Studies 50,3: 475-491. [doi: 10.1111/j.1468-5965.2011.02238.x].

Reinecke, Christiane 2008: Policing foreign men and women: Gendered patterns of expulsion and migration control in Germany, 1880-1914. In: Schrover, Marlou; van der Leun, Joanne; Lucassen, Leo; Quispel, Chris (Eds.): Illegal Migration and Gender in a Global and Historical Perspective. Amsterdam: IMISCOE Press: 57-82.

Reinhart, Carmen; Rogoff, Kenneth 2009: This time is different: eight centuries of financial folly. Princeton, NJ: Princeton University Press.

Robinson, Neremiah 1953: Convention relating to the status of refugees. Its history, contents and interpretation. New York: Institute of Jewish Affairs.

Schain, Martin; Zolberg, Aristide; Hossay, Patrick 2002: The Development of Radical Right Parties in Western Europe. In: Schain, Martin; Zolberg, Aristide; Hossay, Patrick (Eds.): Shadows over Europe: The Development and Impact of the Extreme Right in Western Europe. New York: Palgrave: 3-17.

Schutte, Julian 1991: Schengen: its meaning for the free movement of persons in Europe. In: Common Market Law Review 28,5: 49-570.

Shapiro, Martin; Stone, Alec 1994: The New Constitutional Politics of Europe. In: Comparative Political Studies 26,4: 397-420.

Simmonds, Kenneth R. 1988: The concertation of Community migration policy. In: Common Market Law Review 25,1: 177-200.

Simpson, Sir John Hope 1939: The Refugee Problem. Report of a Survey. London: Oxford University Press.

Sjoberg, Tommie 1991: The Powers and the Persecuted. The Refugee Problem and the Intergovernmental Committee on Refugees. Lund: Lund University Press.

Skran, Claudena 1995: Refugees in Inter-war Europe. Oxford: Clarendon Press.

Sniderman, Paul; Peri, Pierangelo; De Figueiredo, Rui; Piazza, Thomas 2000: The Outsiders: Prejudice and politics in Italy. Princeton: Princeton University Press.

Stiglitz, Joseph 2010: Freefall. Free Markets and the Sinking of the Global Economy. London: Penguin.

Thompson, Dorothy 1938: Refugees: A World Problem. In: Foreign Affairs 16,3: 375-387.

Times 2008: EU clears Berlusconi over Roma gypsies, 04.09.2008.

Timmer, Ashley; Williamson, Jeffrey 1998: Immigration Policy Prior to the 1930s: Labor Markets, Policy Interactions, and Globalization Backlash. In: Population and Development Review 24,4: 739-771.

Torpey, John 2003: Passports and the Development of Immigration Controls in the North Atlantic World during the Long Nineteenth Century. In: Fahrmeir, Andreas; Faron, Olivier; Weil, Patrick (Eds.): Migration control in the North Atlantic World. New York: Bergahn Books: 73-91.

Welch, Claude 2001: Introduction. In: Welch, Claude (Eds.): NGOs and Human Rights: Promises and Performance. Philadelphia: University of Pennsylvania Press: 1-22. 
A German translation of this reviewed and author's authorised original article by the Federal Institute for Population Research is available under the title "Stärkerer Einfluss, weniger Wohlwollen. Reaktion zwischenstaatlicher Organisationen in Westeuropa auf die unerwünschte Migration in wirtschaftlichen Krisenzeiten im Vergleich", DOI 10.4232/10.CPOS-2011-18de or URN urn:nbn:de:bib-cpos-2011-18de3, at http://www.comparativepopulationstudies.de.

Date of submission: 20.09 .2011

Date of Acceptance: 10.05 .2012

Dr. Irial Glynn (₫). School of History and Archives, University College Dublin. Dublin, Ireland. E-Mail: irial.glynn@ucd.ie.URL: https://sites.google.com/site/irialglynn/home 


\section{Comparative Population Studies - Zeitschrift für Bevölkerungswissenschaft}

wWw.comparativepopulationstudies.de

ISSN: 1869-8980 (Print) - 1869-8999 (Internet)

Published by / Herausgegeben von

Prof. Dr. Norbert F. Schneider

Federal Institute for Population Research

D-65180 Wiesbaden / Germany

Managing Editor /

Verantwortlicher Redakteur

Frank Swiaczny

Editorial Assistant /

Redaktionsassistenz

Katrin Schiefer

Language \& Copy Editor (English) /

Lektorat \& Übersetzungen (englisch)

Amelie Franke

Copy Editor (German) /

Lektorat (deutsch)

Dr. Evelyn Grünheid

\section{Layout / Satz}

Beatriz Feiler-Fuchs

E-mail: cpos@destatis.de

\author{
Scientific Advisory Board / \\ Wissenschaftlicher Beirat \\ Jürgen Dorbritz (Wiesbaden) \\ Paul Gans (Mannheim) \\ Johannes Huinink (Bremen) \\ Marc Luy (Wien) \\ Clara H. Mulder (Groningen) \\ Notburga Ott (Bochum) \\ Peter Preisendörfer (Mainz)
}

\section{Board of Reviewers / Gutachterbeirat} Martin Abraham (Erlangen) Laura Bernardi (Lausanne) Hansjörg Bucher (Bonn) Claudia Diehl (Göttingen) Andreas Diekmann (Zürich) Gabriele Doblhammer-Reiter (Rostock) Henriette Engelhardt-Wölfler (Bamberg) E.-Jürgen Flöthmann (Bielefeld) Alexia Fürnkranz-Prskawetz (Wien) Beat Fux (Zürich) Joshua Goldstein (Rostock) Karsten Hank (Köln) Sonja Haug (Regensburg) Franz-Josef Kemper (Berlin) Michaela Kreyenfeld (Rostock) Aart C. Liefbroer (Den Haag) Kurt Lüscher (Konstanz) Dimiter Philipov (Wien) Tomáš Sobotka (Wien) Heike Trappe (Rostock) 